\title{
Symbolic Communication Behavior Construction of Peasant in the Konawe Industrial Zone
}

\author{
Sumadi Dilla ${ }^{1}$, Weka Widayati ${ }^{2}$, Bahtiar ${ }^{3}$, Dasmin Sidu ${ }^{4}$ \\ ${ }^{1,3}$ Faculty of social and political sciences, Halu Oleo University, Indonesia \\ ${ }^{2}$ Faculty of Sciences and Earth Technology, Halu Oleo University, Indonesia \\ ${ }^{4}$ Faculty of Agriculture, Halu Oleo University, Indonesia
}

\begin{abstract}
This research analyzes symbolic communication behavior between peasants with the industry employee in an intercultural communication perspective at Morosi sub district Konawe regency, southeast Sulawesi. Research method used is qualitative with symbolic interaction approach. The research informant, peasant and Konawe industry employee, is by means of purposive sampling and snowball technique. The result of the research finds two schemes on symbolic communication behavior at peasant. First, communication behavior in self and the second is interpersonal communication behavior. Self communication behavior of peasant is by phases: self evaluation, self confirmation, self socialization, self adjustment and self concept structuring that form self category, "old self" and "new self". Interpersonal communication behavior of peasant is bring into reality by verbal symbol that are traditional language and Indonesian language; and non verbal symbol that is local attribute of speaking and writing which form certain category. There are symbols appearance, communication setting and arrangement mechanism of communication orientation in peasant symbolic behavior in expressive and impressive manner based on personality, the growing social and communal situation and their communication completing.
\end{abstract}

Keywords: Interaction, Interpersonal Communication, Symbolic Communication Behavior

\section{Introduction}

The consequences of the Konawe industry zone presence in Morosi sub district Konawe regency, Southeast Sulawesi is the pressure of agriculture scope especially the peasant, the mobilization of outside labor force, the creating of new environment and the replacing of livelihood. The impact complexity motivates the self consciousness of people around to adapt with the changes happened. For people around the industry zone, the changes push the system change of perception, opinion, orientation, attitude and behavior. If before the people around industry zone in Morosi were oriented in agriculture and peasant, slowly their habits, methods, and activities increase to become non-agricultural society or industrial basis. This condition could be observed from the presence of new habit and method beside their routine activities all this time like the appeal of new trade and work field as a phenomenon in growing society. (The study of environment impact analysis, Konawe Industry Zone, 2014)

The observation shows that the cultural social dynamics of people around the industry zone is by emerge of inter-cultural culture and communication interaction at individual and people group level. In the communication and cultural context, first indication of change appears on the people openness, cooperative, compromise, communicative and adaptive with new culture. In the cultural contact process, the peasant experience confirmation and self adaptation so that it forms new self awareness. Finally, inter-cultural communication process forms peasant symbolic communication behavior that is unique in any kind of communication phenomenon context daily. If at first symbolic communication behavior of Morosi people especially the peasant who often communicate with their fellow, so that since the center of Industry Company, the peasant develop their symbolic communication behavior with the company employee.

Some characteristics and habits of peasant symbolic communication behavior around Konawe industry zone like peasant in-self communication, peasant fellow and communication in peasant family, so that the condition slowly begins to develop to communication between the peasant and the industry company employee. The growing of the symbolic communication behavior is related to their consciousness and experience as a result from the entering of new culture. This influences symbol system, attribute and people look in communicating.

In the usage level of symbol, attribute and look, peasant symbolic communication experiences the increasing and the broadening of self purpose. If with peasant fellow and people around industry zone, peasant symbolic communication tends to maintain symbols and attributes of agricultural people. While if communication happens between peasant and industry company employee, their communication behavior is showed symbols and attributes of new industrial people. Some phenomenon happened in peasant symbolic communication behavior around Konawe industry zone. First, in the context of peasant fellow communication, their inter-personal communication is so intimate, strong and familiar and the channel is dominated by speaking (mouth of communications) with the usage of symbol (accent), language and local attribute. Second, in the context of communication happening between peasant and the industry company employee, inter-personal communication of peasant is well mannered, friendly and professional with the blend of speaking communication channel, written communication 


\section{International Journal of Science and Research (IJSR) \\ ISSN (Online): 2319-7064 \\ Index Copernicus Value (2013): 6.14 | Impact Factor (2014): 5.611}

and the usage of Indonesian symbol, accent and language and also a little foreign term limited in English and China.

The form of two schemes in peasant symbolic communication behavior around Konawe industry zone shows that there is mechanism of dynamic self concept. In the internal way at one side symbol, attribute, accent, language and local culture are developed and broadened their meaning in the peasant symbolic behavior. The realization of the two schemes peasant symbolic communication has certain reason, motive, purpose and category. The peasant symbolic communication behavior is presented alternately in accordance with need and situation by means of creating front stage between peasant and industrial company employee and back stage between peasant fellow. The problem formulation is: (1) How the scheme mechanism of peasant personal communication around; (2) How peasant symbolic behavior (verbal and non verbal) in various communication phenomenons around Konawe industry zone; and (3) How the peasant use symbolic behavior in various communication contexts.

\section{Literature Review}

\section{Interaction, intercultural communication and symbolic} communication behavior

This study tries to understand and explain the relation of interaction, inter-cultural communication and symbolic communication behavior in society. Many studies and scientific literature explain about interaction, inter-cultural communication and symbolic communication behavior. Narwoko-Suyanto (2004) explained that interaction describes the relationship between one action and the other action which is uncertain to alternate and to explain together in certain social system. Hugo F. Reading in Soeprapto, R (2002) told that interaction is relationship arranged from many people which happened between social units or components exist. The interaction could be happened between individual, individual with group and group. Doing interaction, one can know each other, cooperate, organize, compete and even cause conflict. Soekanto, (2007) said in a interaction social process could be happened if there are two criterias or qualifications that are the presence of socialcontact and communication.

Tubbs and Moss (1996) define communication as a process of creating meaning between two people or more. Meanwhile Levine and Adelman who quoted by Mulyana (2004) give the meaning of communication as a process to share meaning by verbal and nonverbal behavior that involve two people or more. Gudykunst and Kim (1992) define communication (inter-cultural) as a transactional process, symbolic that involve the meaning giving among people (from different culture). Thus, communication can be happened if the source arouses response to the acceptance by delivering message in the form of sign or symbol both verbal (words) and nonverbal, involve participant (people) without having to confirm that the two sides who communicate have the same symbol system. According to Hofstede (1994), symbol is consist of word, jargon, signal, picture, clothes, appearance or status symbol object which contain a certain meaning that only known by cultural followers.

Hofstede mentions that culture is consist of meaning values, symbol and ritual that form cultural manifestation applied and have meaning. Trenholm and Jensen quoted by Mulyana (2004) defines culture as a set of values, beliefs, norms, customs and traditions, rules and codes that socially define people group, bound them each other and give together consciousness. By means of culture, perception about world, reality and how to think about our self, our other people, how to reach aim and how to alternate would guide us. In other words according to Goodman (1994) human culture has growing up to the point that enables culture substitute instinct to determine every idea and action.

The relationship between communication and culture can be seen from the explanation of Alfred G. Smith quoted by Mulyana (2004). Culture is a code that we learn together and for that communication is needed. Communication needs coding and symbols have to be learned so that involving expectation, perception, action choice and interpretation influenced by certain cultural environment. Edward T. Hall (1996) called this as two important inseparable entities, culture is communication and communication is culture. Culture appears from communication and becomes part of communication behavior, and finally communication also has a share in deciding, maintaining, developing or inheriting culture.

It means culture guides individual or society in how to communicate both verbal and nonverbal. So every communication practice basically is a cultural representation or a map of complex reality (culture). Communication role in the inter-cultural interaction process until the symbolic behavior establishment of someone, group or ethnic is intended to exchange and to share meaning at the symbols delivered among individuals. Porter and Samovar quoted by Liliweri (2001) said with culture human beings learn to communicate, look at their world, form categories, concepts and special labels for them including their ethnic identity. In the other words like W. I. Gorden and Edward T. Hall (Dilla, 2007) said that a certain people group will have different customs and manners with other people group in social living. The purpose is that each ethnic identity category shows the difference in self-image and self-concept in their social world. The similarity and the difference of culture then influence the system of symbol, attribute, opinion, setting and individual communication action and form certain symbolic behavior.

The understanding of culture and communication on individual, group or ethnic in inter-cultural context will be able to explain communication behavior related with the form mechanism of situational ethnic identity, symbol system, attribute, setting and the use of ethnic identity. From that argumentation, the process of cultural contact or the realization of one ethnic identity in the multicultural society system involve a set of verbal and nonverbal symbol system and communication setting that enable individual to do an interaction. 


\section{International Journal of Science and Research (IJSR) \\ ISSN (Online): 2319-7064}

Index Copernicus Value (2013): 6.14 | Impact Factor (2014): 5.611

Gold and Kolb (1964) in Roggers (1993) explained that communication behavior is an action or a response in the existing communication environment and situation like thinking, knowledgably and perspective, experience and do an action that followed by someone, family or society in looking for and spreading information. Communication behavior is all activities that intends to seek and to get information from various sources and to spread them to anyone who need. Communication behavior basically is oriented at purpose in the meaning someone's behavior commonly is motivated with the desire to get certain purpose. Roggers (1993) explained that communication behavior is a habit of individual or group in accepting and looking for information that indicated with participation, relationship with social system, cosmopolite, relationship with change agent, media nearness, being active in looking for information, knowledge about new thing in the innovation.

\section{Opinion Frame}

This research began from interaction phenomenon and intercultural communication of peasant with the employee of Konawe industrial company in social environment. The symbolic communication behavior of peasant involves any kind of verbal, nonverbal and special attribute. The symbol realization is carried out by setting, individual action and meaning in two schemes communication and communication phenomenon context. The using of the two schemes and the communication context is in turns with the reason, motive and purpose to complete communication in doing activities daily. To understand that it's needed a deepen theoretical approach with carrying phenomenology Alfred Schutz as theory screen in the theory frame of symbolic interaction from George H. Mead and dramaturgy Goffman as a one unity that complete each other.

Phenomenology perspective observes the symbolic communication action and behavior of peasant around industrial zone is much influence by self consciousness and social reality. Little John (1996) argued that how we think and behavior in daily living generally determined in how we understand reality. Schutz in Sukidin (2002) tends to see social agent in certain communication situation about self and individual concept that construct meaning by specification process. Campbell (1994) mentions that communication meaning by symbols as subjectivism pattern. The meaning relationships are organized together also by specification process (stock of knowledge). Following Schutz, Little John and Campbell, the symbolic communication behavior of peasant is unpredictable, so that it must be examined and according to subjective perspective including the motive, reason and purpose of their behavior.

The using of symbolic interaction theory in peasant communication behavior is based on the process of peasant interaction and communication with the employee of industrial company at Morosi sub district. The symbolic interaction opinion that human tends to act or change his action is based on various reasons, motives and certain purposes involves amount of symbols, attributes and settings consciously and expressly. Becker in Mulyana (2002) mentioned the using of symbol, attribute, accent, language; local and nonlocal culture reflects the peasant symbolic communication behavior in their social and own life. The peasant symbolic behavior that often changes and grows up from one phenomenon context to the other one indicates communication is social. The consequences is that all opinions, senses and actions of peasant often change in communication process are the process of experience, knowledge, management result, the interpretation of verbal and nonverbal symbols in their social world.

Little John (1996) and Watson (Sukidin, 2002) said symbolic interaction contains basic premise about communication and society. Communication process links individual adaptation to outer world, symbol system, language, signal movement or meaningful action. Interaction among people involves the exchange of symbols that happened face to face in daily life. So peasant communication with other people can have meaning if each has significant symbol. Giddens (Soeprapto, 2002) by means of verbal and nonverbal language enables human to become conscious creature that are individuality and social so demanded continuously to think object in a symbolic manner. It means all human behaviors and actions are formed and limited by complex language and symbols. They are influenced by individual culture in collective and personal manner included peasant around Konawe industrial zone. This argumentation is strengthened more by assumption from Ritzer (2004) that all social precede individual opinion both logical and temporary.

The using of dramaturgy theory from Erving Goff man is to identify and to explain the using of communication space in peasant symbolic behavior around Konawe industrial zone. Dramaturgy theory focuses on special expressions implied in verbal and nonverbal behavior in understanding meaning and impression from other people action. Dramaturgy concludes that social life can be seen from two sides that are front region as social area and back region as personal area. So that, one self is personal and social. In other words, one self is not just for actor but more as the result of dramatic interaction between an actor and audients. So it happens to peasant around Konawe industrial zone that tend to show symbolic behavior that often change and take turns according to need, hope and personal or social situation. Explicitly this study tries to reveal the meaning of peasant symbolic communication culturally and contextually in forming a group. Researcher summarizes framework of opinion in a draft as follows Figure 1.

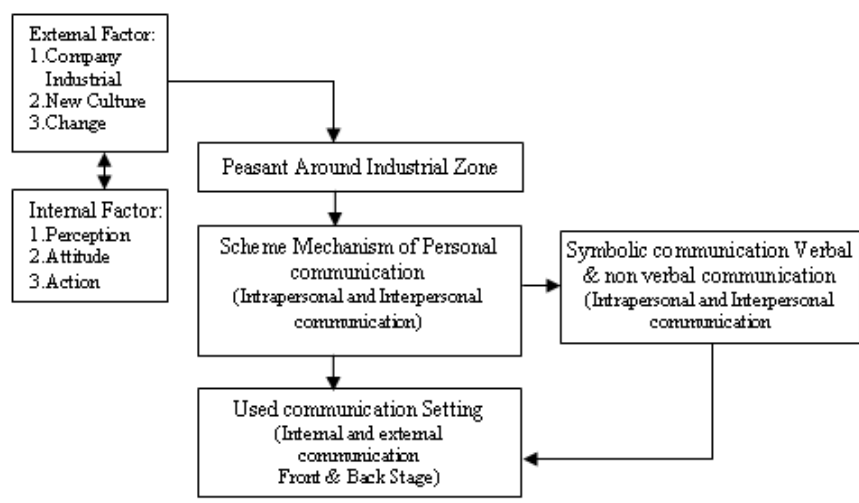

Figure 1: Research framework of opinion 


\section{International Journal of Science and Research (IJSR) \\ ISSN (Online): 2319-7064}

Index Copernicus Value (2013): 6.14 | Impact Factor (2014): 5.611

\section{Research Method}

This is a research of phenomenology perspective qualitative as emits study subjectively. The location of the research is in Konawe industrial zone, Morosi sub district, Konawe regency, Southeast Sulawesi. The subject of the research is peasant who is domiciled, settle and work around Konawe industrial zone. The research information is by purposive sampling technique and snowball technique that is peasant who sells their agricultural land and do not sell to industrial company. The object of the research is peasant symbolic communication behavior that is interpreted, explained, used and symbolized in communication process both internal of peasant and external of wide society.

\section{Results and Discussion}

The scheme mechanism of personal communication around Konawe industrial zone consists of two schemes, contexts and media with certain phase process. The scheme of peasant personal communication taking place used first scheme, intrapersonal communication; second, interpersonal communication. The communication phenomenon context formed is communication of internal context or peasant fellow and external context or peasant with industrial company employee. Communication media or socialization used consists of communication media in family and group communication or peasant fellow relative, and people and the other around Konawe industrial zone.

Table 1: The scheme mechanism of peasant communication around Konawe industrial zone

\begin{tabular}{|c|c|c|c|}
\hline $\begin{array}{c}\text { Communication } \\
\text { Scheme }\end{array}$ & \begin{tabular}{|c|} 
Communication \\
Phenomenon \\
Context
\end{tabular} & $\begin{array}{c}\text { Self } \\
\text { Mechanism }\end{array}$ & $\begin{array}{c}\text { Communication } \\
\text { Media }\end{array}$ \\
\hline $\begin{array}{l}\text { 1. Intrapersonal } \\
\text { Communication }\end{array}$ & \begin{tabular}{|c|} 
Internal \\
Communication \\
(Communication \\
in peasant self)
\end{tabular} & $\begin{array}{c}\text { Self } \\
\text { evaluation, } \\
\text { Self } \\
\text { confirmation } \\
\text { (generally) } \\
\end{array}$ & $\begin{array}{c}\text { Intrapersonal, } \\
\text { family, relatives } \\
\text { and peasant } \\
\text { community } \\
\text { (peasant group) }\end{array}$ \\
\hline $\begin{array}{l}\text { 2. Interpersonal } \\
\text { Communication }\end{array}$ & \begin{tabular}{|c|} 
External \\
Communication \\
(peasant fellow, \\
peasant with \\
industry \\
employee)
\end{tabular} & $\begin{array}{c}\text { Self } \\
\text { socialization, } \\
\text { Self adaptation } \\
\text { and structuring } \\
\text { self concept } \\
\text { (specifically) }\end{array}$ & $\begin{array}{c}\text { Interaction, } \\
\text { interpersonal } \\
\text { communication, } \\
\text { works } \\
\text { organization of } \\
\text { social } \\
\text { participation. }\end{array}$ \\
\hline
\end{tabular}

Research result, 2016

At the intrapersonal communication scheme, all peasants intensely build communication in themselves as a whole happened in communication phenomenon context internally by self mechanism covering self evaluation and confirmation. The communication process in self is happened spontaneously and generally about everything concerning their main work as peasant, peasant profession in the future and agriculture for themselves, their family and their community. This scheme mechanism is intended to the perpetuity of peasant group and community. By means of self confirmation and evaluation, the peasants actually strengthen their profession limit both individual, family and peasant community toward the situation of present. The intrapersonal communication scheme is carried out by intrapersonal communication media, family communication and group communication (peasant community).

At the interpersonal communication scheme, all peasants dynamically are happened in communication phenomenon context externally that are communication with peasant fellow and peasant with industrial company employee. Self mechanism on peasant is carried out partially and selective about social cultural environment that growing up at this time. At the self mechanism process information selectivity is happened about the existence of peasant profession and agriculture for people that is specific by means of self evaluation, socialization and adaptation so that the peasants build self concept, identity and their role widely in society. This communication scheme becomes the representation of new self experience and consciousness for peasant when communicating with the employee of the industrial company in any situation. The scheme is brought into reality by communication media covering interaction, interpersonal communication, social participation, work organization in industrial zone environment.

The two schemes of peasant's personal communication form two identity categories that are general and specific. The peasant's general identity is made based on work limitation, profession and family structure. While the peasants specific identity is made based on condition, situation, new culture by the presence of new and important people (new significant others) as depiction according to Berger and Luckmann (1990). Mead in Mulyana (2002) explained the two identities intended as the process of internalization and externalization for individual (peasant) and society.

The research result reveals the reason, the motive, the aim of peasant's personal communication scheme and the two formed peasant identity categories. There are variety of interaction and communication skill as impressive management strategy and tactics both peasant fellow and peasant with industrial company employee, that are Figure 2.

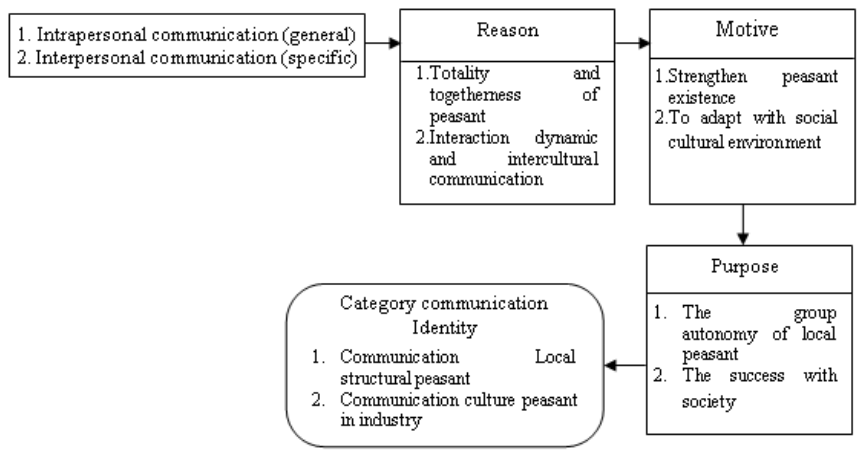

Figure 2: The scheme of reason, motive and purpose; and the of peasant symbolic communication category

Communication setting formed and used by peasant around Konawe industrial zone is oriented at general and specific. Each orientation is begun with the emerge of primary and secondary communication setting and used at back stage and front stage. To make clear, we can see from the Table 2. 


\section{International Journal of Science and Research (IJSR) \\ ISSN (Online): 2319-7064 \\ Index Copernicus Value (2013): 6.14 | Impact Factor (2014): 5.611}

Table 2: The communication setting that peasant form and use

\begin{tabular}{|l|c|l|}
\hline The orientation of communication Setting Management & $\begin{array}{c}\text { Formed Communication } \\
\text { Setting }\end{array}$ & \multicolumn{1}{|c|}{ The Using } \\
\hline $\begin{array}{l}\text { [1] General: Loyalty and solidarity of peasant profession, } \\
\text { region locality, peasant group and the existence of } \\
\text { significant others: family, relatives }\end{array}$ & $\begin{array}{c}\text { Past setting: } \\
\text { Main communication } \\
\text { area (primary) }\end{array}$ & $\begin{array}{l}\text { (1) At back stage and communal valid } \\
\text { (2) Happened in peasant fellow around industrial } \\
\text { (3) Rare to meet and majority }\end{array}$ \\
\hline $\begin{array}{l}\text { [2] Specific: experience, knowledge and individual } \\
\text { consciousness, new values and the peasant of new } \\
\text { industrial company official as the generalized } \\
\text { modified to become new significant others: work } \\
\text { partner business. }\end{array}$ & $\begin{array}{c}\text { Present setting: } \\
\text { Additional } \\
\text { communication area } \\
\text { (secondary) }\end{array}$ & $\begin{array}{l}\text { (1) At front stage and personal valid } \\
\text { business partner }\end{array}$ \\
\hline
\end{tabular}

Research Result, 2016

The research result found the two arrangement orientation of communication setting that peasant form and use in interacting and communicating within society is that: (1) general orientation, formed past communication setting as primary main communication arena, communal valid and used at back stage zone of peasant community; (2) specific orientation, formed present communication setting as secondary additional communication arena, personal valid and used at front stage zone. The two setting orientation formed and used as peasant communication arena around industrial zone show the symbolic behavior by turns and changed like communication symbols stage. Mulyana (2002) called it as physical situation that has to exist when someone has to do a show.
The peasant symbolic communication behavior around Konawe industrial zone can be seen from the use of communication symbols that are (1) verbal symbol; (2) nonverbal symbol. The peasant symbolization is happened in two communication phenomenon contexts that are; (1) the internal communication context of communication phenomenon in peasant community, and (2) the communication phenomenon context with other ethnic. Various peasants internally in various interaction and communication situation are divided into two communication phenomenon contexts. We can see from the table as follows to make clear.

Table 3: The Using peasant symbolic behavior communication according to the identity category, contexts, and setting of communication

\begin{tabular}{|c|c|c|c|c|}
\hline Verbal Symbol & Non Verbal Symbol & $\begin{array}{c}\text { Communication } \\
\text { Identity of } \\
\text { Peasant } \\
\end{array}$ & $\begin{array}{c}\text { Communication } \\
\text { Context }\end{array}$ & $\begin{array}{l}\text { Communication } \\
\text { Setting Formed }\end{array}$ \\
\hline $\begin{array}{l}\text { [1] Word, term/sentence and } \\
\text { traditional language (dominant, } \\
\text { often) } \\
\text { [2] Word, term, sentence in } \\
\text { Indonesian language (selective, } \\
\text { rare) } \\
\text { [3] Accent local dialect Speaking } \\
\text { communication dominant, } \\
\text { various use of symbol system } \\
\text { and two language }\end{array}$ & 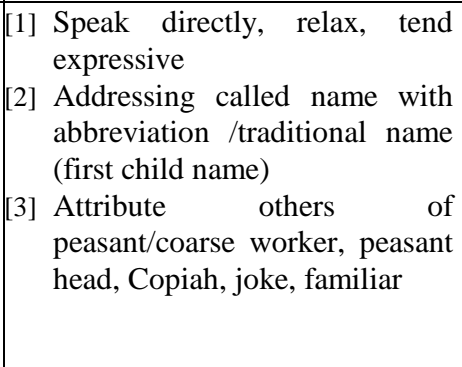 & $\begin{array}{l}\text { Communication } \\
\text { of Local } \\
\text { Structural } \\
\text { Peasant } \\
\text { (General) }\end{array}$ & $\begin{array}{c}\text { Internal } \\
\text { Communication } \\
\text { (Family, relatives, } \\
\text { Local peasant } \\
\text { community) }\end{array}$ & $\begin{array}{c}\text { Primary } \\
\text { Communication } \\
\text { Area } \\
\text { (back stage) }\end{array}$ \\
\hline $\begin{array}{l}\text { [1] Word, term/Indonesian sentence } \\
\text { [2] Word, sentence or term in } \\
\text { foreign } \\
\text { [3] Various of two symbolic } \\
\text { language and speaking, writing } \\
\text { communication happened }\end{array}$ & $\begin{array}{l}\text { [1] Clothes attribute neat, industry } \\
\text { worker often shake hands } \\
\text { [2] Easy to great, smile and } \\
\text { friendship } \\
\text { [3] Thrifty speaking, low profile, } \\
\text { impressively }\end{array}$ & $\begin{array}{l}\text { Communication } \\
\text { of cultural } \\
\text { Worker peasant } \\
\text { (specific) }\end{array}$ & \begin{tabular}{|c|} 
External \\
communication \\
(Formal work \\
environment in \\
industrial zone, \\
formal organization)
\end{tabular} & $\begin{array}{c}\text { Secondary } \\
\text { communication } \\
\text { area } \\
\text { (front stage) }\end{array}$ \\
\hline
\end{tabular}

Research result, 2016

The research result found the peasant symbolic communication behavior number one at the back stage primary communication arena, prominent verbal symbol used is the use of word, term or more dominant/often used local language and a little Indonesian language. There are various uses of symbol system, word, term, accent and language. While the prominent nonverbal symbol is speaking in direct, relax, tend to expressive. Even the name addressing uses the abbreviation of prefix name or first child name for married people. The use of peasant society clothes attribute, easy to speak and to smile as intimate sign, solidarity and friendship, brotherhood and family atmosphere. The peasant symbolic communication behavior number two at the front page secondary communication arena, prominent verbal symbol used is the use of word, term or Indonesian language and a little foreign language (English, China). The prominent peasant nonverbal behavior is showed by the use of language impressively, thrifty in speaking, is modest with neat and official clothes, often shake hands, easy to greet and smile. There is various use of language symbol system agree with peasant situation and need. According to Goffman in Ritzer (2004) the tendency of peasant symbolic communication behavior is as impression management product by culture borrowing. 


\section{International Journal of Science and Research (IJSR) \\ ISSN (Online): 2319-7064}

Index Copernicus Value (2013): 6.14 | Impact Factor (2014): 5.611

\section{Conclusion}

The construction of peasant symbolic communication behavior around Konawe industrial zone as follows: (1) generally the peasant communication mechanism happened in two schemes that are intrapersonal communication that has communication context (internal and external). The process is by self mechanism (self evaluation, self strengthen), self socialization, self adaptation, self concept management which carried out by communication media of intrapersonal, family, peasant community, interaction, interpersonal communication, work organization and social participation. The communication scheme has reason, motive, the purpose of certain identity category; (2) the peasant verbal communication symbols in peasant internal communication consists are: (a) speaking communication, (b) various use of word, term, sentence, accent, expressive traditional and Indonesian language and specific appearance of local peasant. The peasant nonverbal communication symbol in external communication is revealed by: (a) speaking/writing communication combination, (b)various word, term, sentence, accent, impressive Indonesian and foreign language and the look of a professional worker; and (3) The communication setting that formed and used by peasant covering: first, general orientation, has past primary setting and used communally at back stage zone. Second, specific orientation has presented secondary setting and used at front stage zone personally.

\section{References}

[1] Barth, Fredrik., 1988, Translator: Nining I. Soesilo, Ethnic Groups and Limitations, Jakarta; UI-Press.

[2] Berger, Peter L., \& Luckmann, Thomas. 1990. Social Commentary on reality; Treatise on Sociology of Knowledge. Jakarta: LP3ES.

[3] Cambell, Tom, 1994, Seven Theory of Human Society, interpreter Budi Hardiman, Seven Social Theory, Sketch, Ratings and Comparisons, Yogyakarta; Canisius

[4] Dilla, Sumadi., 2007, Development Communication, Integrated Approach, Bandung; Simbiosa.

[5] Goodman, Neal R. 1994, Cross Cultural Training for the Global Executive, Dalam Richard W. Brislin dan Tomoko Yoshida, ed, Improving Intercultural Communication, Modules. Thousand Oaks : Sage.

[6] Griffin, Em., 2003, A First Look At Communication Theories, Fifth Edition, New York, McGraw-Hill

[7] Gudykunst, William B, dan Young Yun Kim, 1992, Communicating with Strangers : An approach ti Intercultural Communication. Edisi ke 2, New York : McGraw-Hill.

[8] Hall, Edward T. Dan William Foote Whyte., 1996, inter-cultural Communication: An Overview Anthropological. In Deddy Mulyana and Jalaluddin Rahmat, ed. Intercultural communication: A Guide to Communicating with people of different cultures. Remaja Rosdakarya, Bandung.

[9] Hofstede, Geert, 1994., Cultures and Organization : Intercultural Cooperation and its Importance for Survival, London : HarperCollins.
[10] Hogg, M.A. \& Abram, D.1988. Social Identification: A Social Psychology of Intergroup Relation and Group Processes. London; Routledge.

[11] Liliweri, Alo., 2001, Slot-Slot Intercultural Communication,Yogyakarta; Pustaka Pelajar.

[12] Littlejohn, Stephen W., 1996, Theories of Human Communication, edisi ke-5, Terjemahan. BelmontCalifornia; Wadsworth.

[13] Mulyana D, 2002, Qualitative Research Methodology. New Paradigm of Communication Science and Social Studies, Bandung; Remaja Rosda Karya.

[14] Mulyana D, 2004, Effective Communication: A CrossCultural Approach, Bandung; Remaja Rosda Karya.

[15] Mulyana D and Solatun 2007, Communications Research Methodology: Examples of Qualitative Research with Practical approach, Bandung; Remaja Rosda Karya.

[16] Narwoko, J. Dwi \& Bagong Suyanto, 2004, Text Introduction to Sociology and Applied, Prenada Media, Jakarta

[17] Ritzer, George., 2004, Modern Sociological Theory, Jakarta, Kencana Prenada Media Group

[18] Roggers, Everett M, 1983, Diffusion of Inovation , The Free Press New York

[19] Soekanto, Soerjono, 2007, An Introduction to Sociology, Gramedia Jakarta

[20] Soeprapto, Riyadi., 2002., Symbolic interactionist; Modern Sociological Perspective, Yogyakarta, Averroes Pres bekerjasama Pustaka Pelajar.

[21] Sukidin, Basrowi., 2002, Qualitative Research Methods Micro Perspective, Surabaya; Insan Cendekia.

[22] Suparlan, Parsudi 1999, Pluralistic Society and InterTribal Relations, Jakarta; Gramedia.

[23] Tubbs, Stewart L, dan Sylvia Moss, 1996. Human Communication I and II, Indonesian edition, translators Deddy Mulyana, Bandung: Remaja Rosdakarya. 